\title{
Effect of Grafting Time on Success of Softwood Grafting in Mango (Mangifera indica L.)
}

\author{
Ajay Kumar Karna ${ }^{1 *}$, D.K. Varu ${ }^{1}$, Manas Kumar Patel ${ }^{2}$ and Puja Archana Panda ${ }^{1}$ \\ ${ }^{1}$ Department of Horticulture, College of Agriculture, Junagadh Agricultural University, \\ Junagadh-362001, Gujarat, India \\ ${ }^{2}$ Department of Fruit Science and Horticultural Technology, College of Agriculture, Orissa \\ University of Agriculture and Technology, Bhubaneswar-751003, Odisha, India
}

*Corresponding author

\begin{tabular}{|c|c|}
\hline \multicolumn{2}{|r|}{ A B S T RA C T } \\
\hline & \multirow{6}{*}{$\begin{array}{l}\text { An experiment was conducted to assess the effect of grafting time on success of softwood } \\
\text { grafting in mango (Mangifera indica Linn) was conducted during 2015-16 at the } \\
\text { Department of Horticulture, College of Agriculture, JAU, Junagadh. Total six treatment of } \\
\text { grafting time comprised of } 15^{\text {th }} \text { August }\left(\mathrm{T}_{1}\right), 30^{\text {th }} \text { August }\left(\mathrm{T}_{2}\right), 15^{\text {th }} \text { September }\left(\mathrm{T}_{3}\right), 30^{\text {th }} \\
\text { September }\left(\mathrm{T}_{4}\right), 15^{\text {th }} \text { October }\left(\mathrm{T}_{5}\right) \text { and } 30^{\text {th }} \text { October }\left(\mathrm{T}_{6}\right) \text {. The study revealed that low } \\
\text { phenol content }(1.23 \%) \text { was recorded in } 15^{\text {th }} \text { September grafting }\left(\mathrm{T}_{3}\right) \text {. Significantly, } \\
\text { highest graft success percentage }(80 \%) \text {, survival percentage }(71.11 \%) \text {, maximum shoot } \\
\text { length }(14.99 \mathrm{~cm}) \text {, number of leaves }(14.85) \text {, plant height }(56.61 \mathrm{~cm}) \text {, Scion girth }(8.81 \\
\mathrm{mm}) \text { and stock girth }(9.25 \mathrm{~mm}) \text { were registered in } 15^{\text {th }} \text { September }\left(\mathrm{T}_{3}\right) \text {, however it was } \\
\text { found at par with } 30^{\text {th }} \text { August }\left(\mathrm{T}_{2}\right) \text {. Highest carbohydrate content }(12.78 \%) \text { and numbers } \\
\text { of days for shoot emergence }(12.07) \text { was noted at } 30^{\text {th }} \text { August }\left(\mathrm{T}_{2}\right) \text {. Similarly, lowest } \\
\text { carbohydrate content }(11.52 \%) \text {, maximum days to shoot emergence }(15.40) \text {, minimum } \\
\text { success percentage }(23.33 \%) \text {, survival percentage }(20.00 \%) \text {, shoot length of scion }(9.85 \\
\text { cm), total number of leaves }(8.66) \text {, plant height }(50.67 \mathrm{~cm}) \text {, scion girth }(6.75 \text { mm and } \\
\text { stock girth }(8.45 \mathrm{~mm}) \text { were noted in } 30^{\text {th }} \text { October }\left(\mathrm{T}_{6}\right) \text { whereas, highest phenol content } \\
(2.95 \%) \text { was noted in } 15^{\text {th }} \text { October }\left(\mathrm{T}_{5}\right) \text {. }\end{array}$} \\
\hline Keywords & \\
\hline $\begin{array}{l}\text { Time, Softwood, } \\
\text { Success percentage, } \\
\text { Growth parameter }\end{array}$ & \\
\hline Article Info & \\
\hline $\begin{array}{l}\text { Accepted: } \\
\text { 17 July } 2018 \\
\text { Available Online: } \\
10 \text { August } 2018\end{array}$ & \\
\hline & \\
\hline
\end{tabular}

\section{Introduction}

The mango (Mangifera indica L.) is belongs to family anacardiaceae originated in South East Asia and one of the important fruit liked by all section of section of people of India. It occupies a prominent place among the fruit crops grown in India. It is also called the king of fruits and known as national fruit of India. Mango was originated in Indian sub-continent during the pre-historic times (Mukherjee, 1998). India is the major producer of mango in the world with an area of 25.15 lakh hector and annual production is 184.31 lakh MT. In Gujarat total area under mango cultivation is about 1.42 lakh hector and production about 11.25 lakh MT (Anon., 2014). Generally the agro climactic condition of Gujarat is very important of mango cultivation. So there is a tremendous scope for increasing the area of 
mango cultivation and this will require selected plants of superior quality and high yield potential. That is only possible when desirable mother trees are used for vegetative propagation. A wide range of variability occurs with regards to fruit size and quality owing to its seeds propagation True-to-type propagules could be multiplied from an elite tree that produces good quality fruits only by asexual methods of propagation. Generally mangos are propagated by many vegetative methods among those softwood grafting has distinct advantages over traditional method like approach grafting which is more tedious, costly and more labour intensive (Reddy et al., 1994). However success of grafting depends upon many grafting time and environmental parameter (Hartman and Kertar, 1972, Patel and Amin, 1981 and Singh et al., 1984). Hence, the present study was undertaken to find out the best time for softwood grafting in mango.

\section{Materials and Methods}

An experiment, on the effect of grafting time on success of softwood grafting in mango (Mangifera indica Linn) was conducted during the year 2015-16 at Sakkarbaug, Fruit Research Station, Department of Horticulture, Junagadh Agricultural University, Junagadh. It was laid out in completely Randomized Design (CBD) with Factorial concept having three repetitions. The experiment was conducted to find out to find out the influence of grafting time on success of softwood grafting in mango. The grafting was performed at 15 days intervals starting from $15^{\text {th }}$ August 2015 to $30^{\text {th }}$ October 2015 which act as treatment $15^{\text {th }}$ August $\left(\mathrm{T}_{1}\right), 30^{\text {th }}$ August $\left(\mathrm{T}_{2}\right), 15^{\text {th }}$ September $\left(\mathrm{T}_{3}\right), 30^{\text {th }}$ September $\left(\mathrm{T}_{4}\right)$, $15^{\text {th }}$ October $\left(\mathrm{T}_{5}\right)$ and $30^{\text {th }}$ October $\left(\mathrm{T}_{6}\right)$. For experiment purpose ten grafts were prepared in each treatment, which are replicated three times. For rootstock purpose the stone are removed from the pulp and treated with sting
@ 2\%, contains carbendazim $(50 \mathrm{WP})$ to avoid any fungal diseases. As the stone have low viability, they were immediately planted on the polythene bags of 12 inch x 10 inch and 300 gauge thickness containing potting mixture of soil and F.Y.M. in the ratio of 2:1. The stones were sown in the $1^{\text {st }}$ June 2015 and the seedlings were ready for grafting on particular date as per programme from $15^{\text {th }}$ August to $30^{\text {th }}$ October 2015. The mature healthy, terminal, vigorous and 3-4 month old shoots were selected for scion and leaves were defoliated 7-10 days before for grafting. Scions were collected from an elite tree. The tree scion shoots were collected from mother trees in the morning time on the day of grafting. Immediately after separation of the scions from the mother tree, they were wrapped in moist cloth and carried in polythene covers to the site of grafting. Grafting was performed on the same day of separation. Watering was done using rose can regularly. The sprouts that emerged from stocks below the graft portion were removed manually as and when they appeared in stocks. Necessary plant protection measures were taken. Five representative plants from each treatment were selected and observed for different growth characters, viz. carbohydrate and phenol content of scion at the time of grafting, days to shoot emergence, success percentage, shoot length of scion, scion girth, stock girth and survival percentage. The observation was recorded two month after grafting operation at intervals of 30 days until 120 days after grafting. The data were analyzed as per method suggested by Panse and Sukhatme (1985).

\section{Results and Discussion}

The data presented in table 1 revealed that treatment differences between different grafting times found significant on carbohydrate and phenol content. The maximum carbohydrate content $(12.87 \%)$ was 
noted in grafting at $30^{\text {th }}$ August $\left(\mathrm{T}_{2}\right)$ whereas, minimum carbohydrate content was found in $30^{\text {th }}$ October $\left(\mathrm{T}_{3}\right)$. The carbohydrate content of scion was increasing from $15^{\text {th }}$ August to $30^{\text {th }}$ August but then it decreased drastically as grafting time increased. It may be due to immaturity stage of shoot and if shoot age is increased, the carbohydrate is decreased due to its maturity. The poor success is that the decrease in carbohydrates was partially responsible for the decrease in graft take, but at that time some other substances was low in supply and was the limiting factor at that time for graft success. This observation agreed with the finding of Rodrigues et al., (1960) in avocados. The phenol content decreased constantly to a certain level as the grafting time increased and was observed minimum in $15^{\text {th }}$ September grafting $\left(\mathrm{T}_{3}\right)$ but after onwards the phenol content increased. The lowest phenol content may be due to maturity of scion shoots. However, it increased as it becomes over mature. This fact was in accordance with the findings of Baskaran et al., (2008) in jackfruit.

The effect of grafting time was found significant on days to shoot emergence. Lowest days required for sprouting was observed in $30^{\text {th }}$ August $\left(\mathrm{T}_{2}\right)$ followed by $15^{\text {th }}$ September $\left(\mathrm{T}_{3}\right)$. It may be due to higher meristamatic activity and also because of the optimal weather condition prevailing during that period due to which early sprouting occurs. This fact was in accordance with the findings of Sharma and Tiwari (1995) and Prasanth et al., (2007) in mango. It may also be due to abundant supply of carbohydrate and defoliation which initiates bud activation and they are in a position to sprout early. Similar results were also obtained by Zimmerman (1958) and Purbiati et al., (1991) in mango.

Grafting time had significantly influenced on success percentage of grafts. The result reveled that $15^{\text {th }}$ September $\left(T_{3}\right)$ recorded maximum success percentage $(80 \%)$ and at par with $\mathrm{T}_{2}$ and $\mathrm{T}_{1}$. Likewise, minimum success percentage $(23.33 \%)$ was noted in $30^{\text {th }}$ October $\left(\mathrm{T}_{6}\right)$. The maximum success percentage may be due to presence of enough carbohydrate and other food material in the scion and rootstock and the accumulated food material is mobilized for new growth which in turns high meristamatic activity in scion. It may also be due to abundance humidity in atmosphere during $15^{\text {th }}$ August to $15^{\text {th }}$ September resulted in more callusing at graft union as compared to $30^{\text {th }}$ October $\left(\mathrm{T}_{6}\right)$, when humidity is very low in atmosphere. This result was supported by Mandal et al., (2011).Significantly the highest survival percentage $(71.11 \%)$ at 120 days after grafting were recorded when grafting was done on $15^{\text {th }}$ September $\left(\mathrm{T}_{3}\right)$. However, it was found at par with $\mathrm{T}_{1}$ and $\mathrm{T}_{2}$. The higher success of grafting during this grafting time may attributed to the congenial weather conditions like temperature, light, sunshine rate and relative humidity prevailed during these dates, which resulted in increased cell activity leading to better callusing at union of stock and scion. These observations are in agreement with the Tayde et al., (1988), Pereira et al., (2004), Kumar et al., (2006) and Mandal et al., (2012) in mango; Bharad et al., (1999) in tamarind and Giri and Lenka (2008) in wood apple.

Significantly maximum shoot lengths of scion $(13.13,13.89$ and $14.99 \mathrm{~cm})$ were recorded in $15^{\text {th }}$ September grafting during 60,90 and 120 DAG, respectively. The result may be due to favorable climactic parameters during monsoon helped in faster growths which act positively on the rootstock and scion shoot, which might had happened due to the longer time available for growth in meristamatic cells coupled with better physiological process like photosynthesis and lower respiration. This result is similar with Mandal et al., (2011) in mango (Table 2 and 3 ). 
Table.1 Effect of grafting time on carbohydrate, phenol, days to shoot emergence, success percentage and survival percentage of graft

\begin{tabular}{|c|c|c|c|c|c|}
\hline Treatment & $\begin{array}{c}\text { Carbohydrate content } \\
\text { of scion }(\%) \text { at the time } \\
\text { of grafting }\end{array}$ & $\begin{array}{l}\text { Phenol content of } \\
\text { scion }(\%) \text { at the } \\
\text { time of grafting }\end{array}$ & $\begin{array}{l}\text { Days to shoot } \\
\text { emergence }\end{array}$ & $\begin{array}{c}\text { Success } \\
\text { percentage } \\
(\%)\end{array}$ & $\begin{array}{c}\text { Survival } \\
\text { percentage }(\%) \\
\text { at } 120 \mathrm{DAG}\end{array}$ \\
\hline $15^{\text {th }}$ August ( $\left.\mathrm{T}_{1}\right)$ & `12.46 & 1.83 & 12.41 & 74.44 & 63.33 \\
\hline $30^{\text {th }}$ August $\left(T_{2}\right)$ & 12.78 & 1.48 & 12.07 & 77.77 & 68.88 \\
\hline $15^{\text {th }}$ September $\left(\mathrm{T}_{3}\right)$ & 12.67 & 1.23 & 12.14 & 80.00 & 71.11 \\
\hline $30^{\text {th }}$ September $\left(T_{4}\right)$ & 12.15 & 2.45 & 13.99 & 38.88 & 27.77 \\
\hline $15^{\text {th }}$ October $\left(T_{5}\right)$ & 11.95 & 2.99 & 14.82 & 25.55 & 21.11 \\
\hline $30^{\text {th }}$ October $\left(\mathrm{T}_{6}\right)$ & 11.52 & 2.85 & 15.40 & 23.33 & 20.00 \\
\hline S.Em. \pm & 0.038 & 0.014 & 0.051 & 3.703 & 4.69 \\
\hline C.D. at 5\% & 0.11 & 0.04 & 0.14 & 10.69 & 13.54 \\
\hline C.V. $\%$ & 4.80 & 6.59 & 5.05 & 10.82 & 14.63 \\
\hline
\end{tabular}

Table.2 Effect of grafting time on shoot length, number of leaves and plant height at 60, 90 and 120 day after grafting (DAG)

\begin{tabular}{|c|c|c|c|c|c|c|c|c|c|}
\hline \multirow[b]{2}{*}{ Treatment } & \multicolumn{3}{|c|}{60 DAG } & \multicolumn{3}{|c|}{90 DAG } & \multicolumn{3}{|c|}{$120 \mathrm{DAG}$} \\
\hline & $\begin{array}{c}\text { Shoot } \\
\text { length } \\
(\mathrm{cm})\end{array}$ & $\begin{array}{l}\text { Number } \\
\text { of leaves }\end{array}$ & $\begin{array}{l}\text { Plant } \\
\text { height } \\
(\mathrm{cm})\end{array}$ & $\begin{array}{c}\text { Shoot } \\
\text { length } \\
(\mathrm{cm})\end{array}$ & $\begin{array}{l}\text { Number } \\
\text { of leaves }\end{array}$ & $\begin{array}{l}\text { Plant } \\
\text { height } \\
(\mathrm{cm})\end{array}$ & $\begin{array}{c}\text { Shoot } \\
\text { length } \\
(\mathrm{cm})\end{array}$ & $\begin{array}{l}\text { Number } \\
\text { of leaves }\end{array}$ & $\begin{array}{l}\text { Plant } \\
\text { height } \\
(\mathrm{cm})\end{array}$ \\
\hline $15^{\text {th }}$ August $\left(\mathrm{T}_{1}\right)$ & 12.60 & 9.21 & 52.70 & 13.68 & 11.49 & 54.27 & 14.56 & 14.03 & 55.72 \\
\hline $30^{\text {th }}$ August $\left(T_{2}\right)$ & 12.97 & 9.46 & 53.28 & 13.75 & 12.47 & 54.99 & 14.88 & 14.54 & 56.38 \\
\hline $15^{\text {th }}$ September $\left(T_{3}\right)$ & 13.13 & 9.80 & 53.68 & 13.89 & 12.61 & 55.16 & 14.99 & 14.85 & 56.61 \\
\hline $30^{\text {th }}$ September $\left(\mathrm{T}_{4}\right)$ & 9.87 & 7.43 & 50.85 & 10.96 & 8.56 & 52.15 & 12.03 & 9.74 & 53.37 \\
\hline $15^{\text {th }}$ October $\left(\mathrm{T}_{5}\right)$ & 8.58 & 6.27 & 48.89 & 9.44 & 7.79 & 50.13 & 10.25 & 8.98 & 51.16 \\
\hline $30^{\text {th }}$ October $\left(\mathrm{T}_{6}\right)$ & 8.19 & 6.09 & 48.24 & 8.76 & 7.19 & 49.28 & 9.85 & 8.66 & 50.67 \\
\hline S.Em. \pm & 0.037 & 0.027 & 0.09 & 0.027 & 0.023 & 0.128 & 0.012 & 0.026 & 0.145 \\
\hline C.D. at $5 \%$ & 0.10 & 0.08 & 0.26 & 0.07 & 0.06 & 0.37 & 0.03 & 0.07 & 0.42 \\
\hline C.V. \% & 5.30 & 6.22 & 1.76 & 4.19 & 4.60 & 2.04 & 2.58 & 3.44 & 2.12 \\
\hline
\end{tabular}

Table.3 Effect of grafting time on scion and stock girth at 60, 90 and 120 days after grafting

\begin{tabular}{|c|c|c|c|c|c|c|}
\hline \multirow[b]{2}{*}{ Treatment } & \multicolumn{2}{|c|}{60 DAG } & \multicolumn{2}{|c|}{90 DAG } & \multicolumn{2}{|c|}{$120 \mathrm{DAG}$} \\
\hline & $\begin{array}{l}\text { Scion girth } \\
(\mathrm{mm})\end{array}$ & $\begin{array}{l}\text { Stock girth } \\
(\mathrm{mm})\end{array}$ & $\begin{array}{l}\text { Scion girth } \\
(\mathrm{mm})\end{array}$ & $\begin{array}{l}\text { Stock girth } \\
(\mathrm{mm})\end{array}$ & $\begin{array}{l}\text { Scion girth } \\
(\mathrm{mm})\end{array}$ & $\begin{array}{l}\text { Stock girth } \\
(\mathrm{mm})\end{array}$ \\
\hline $15^{\text {th }}$ August $\left(\mathrm{T}_{1}\right)$ & 6.90 & 7.64 & 7.81 & 8.34 & 8.61 & 9.14 \\
\hline $30^{\text {th }}$ August $\left(\mathrm{T}_{2}\right)$ & 7.04 & 7.79 & 7.96 & 8.44 & 8.79 & 9.25 \\
\hline $15^{\text {th }}$ September $\left(\mathrm{T}_{3}\right)$ & 7.03 & 7.75 & 8.14 & 8.47 & 8.81 & 9.25 \\
\hline $30^{\text {th }}$ September $\left(\mathrm{T}_{4}\right)$ & 6.00 & 7.30 & 6.97 & 8.02 & 7.73 & 8.66 \\
\hline $15^{\text {th }}$ October $\left(T_{5}\right)$ & 5.28 & 7.09 & 6.19 & 7.78 & 7.04 & 8.62 \\
\hline $30^{\text {th }}$ October $\left(\mathrm{T}_{6}\right)$ & 5.01 & 7.17 & 5.88 & 7.67 & 6.75 & 8.49 \\
\hline S.Em. \pm & 0.011 & 0.005 & 0.008 & 0.007 & 0.007 & 0.005 \\
\hline C.D. $(P=0.05)$ & 0.03 & 0.01 & 0.02 & 0.02 & 0.02 & 0.01 \\
\hline C.V. \% & 5.15 & 3.17 & 3.83 & 3.16 & 3.17 & 2.40 \\
\hline
\end{tabular}


The result was also found significant and maximum numbers of leaves $(9.80,12.61$ and 14.85) were noted in grafting time $15^{\text {th }}$ September $\left(\mathrm{T}_{3}\right)$ during 60, 90 and 120 DAG, respectively. Whereas, minimum number of leaves recorded in $30^{\text {th }}$ October $\left(\mathrm{T}_{6}\right)$. It may be due to the quick and strong union formation and better nutrient uptake might have caused for better plant growth and more number of leaves per plant.

These findings are in line with the results of Patel and Amin (1981) in mango; Chovatia and Singh (2000) in Jamun and Palande et al., (2004) in Tamarind. The maximum plant heights $(53.68,55.16$ and $56.61 \mathrm{~cm})$ were registered during $15^{\text {th }}$ September $\left(\mathrm{T}_{3}\right)$ at 60 , 90 and 120 DAG, respectively. However, they were found at par with treatment $30^{\text {th }}$ August $\left(\mathrm{T}_{2}\right)$ at 90 and 120 DAG. Lowest plant heights $(48.24,49.28$ and $50.67 \mathrm{~cm})$ were noted at $30^{\text {th }}$ October $\left(\mathrm{T}_{6}\right)$ during all periodicals.

Highest increment of scion $(7.04 \mathrm{~mm})$ was noted in $30^{\text {th }}$ August $\left(\mathrm{T}_{2}\right)$ recorded at 60 days which was at par with $\mathrm{T}_{2}$ but at 90 and 120 days, $15^{\text {th }}$ September $\left(\mathrm{T}_{2}\right)$ recorded highest in scion girth (8.44 and $8.81 \mathrm{~mm}$, respectively) at 90 and 120 DAG as compared to other grafting times. This might be due to the suitable temperature and relative humidity prevailing during this period in nursery condition which was responsible for increment of scion girth.

Significantly maximum stock girth at 60 DAG was noted in $30^{\text {th }}$ August but at 90 $\& 120$ DAG, it was observed in $15^{\text {th }}$ September. This might be due to the suitable temperature and relative humidity prevailing during this period in nursery condition which was responsible for increment of stock girth.

The investigation revealed that better performance in majority of parameter like success and survival percentage, shoot length, plant height, number of leaves, scion girth and stock girth, were observed in grafting on $15^{\text {th }}$ September $\left(T_{3}\right)$.

\section{References}

Anonymous, 1992. Market news service Horticultural products Reports. Mango, March 1992. International Trade Centre. UNCIAD/GATT (17 - C). Geneva, Switzerland, pp. 23.

Bharad, S. G., Gholap, S. V., Dod, V. N. and Bople, S. R. 1999: Seasonal variation in success of softwood grafting of tamarind (Tamarindus indica). Journal of Applied Horticulture, 1: 57-58.

Chovatia, R. S. and Singh, S. P. 2000. Effect of time on budding and grafting success in jamun (Syzygium cumini Skeel). Indian Journal of Horticulture, 57: 255 258.

Giri, B. and Lenka, P. C. 2008. Studied on vegetative propagation of wood apple (Feronia limonia) Department of Horticulture (Orissa University of Agriculture and Technology, Bubaneshwar). Orissa Journal of Horticulture, 36(1): 2008.

Kumar, S., Ram, S. and Singh, C. P. 2000. Success of veneer and cleft grafting at different grafting heights of seedling rootstocks in Dashehari mango. Indian journal of Horticulture, 57(3): 212-214.

Mandal, J., Mandal, B. K., Singh, R. R. and Jaiswal, U. S. 2011. Effect of age of root stock, grafting time and varieties on the success of soft wood grafting in mango. Asian Journal of Horticulture, 6(2): 412-417.

Mandal, J., Mandal, B. K., Singh, R. R. and Jaiswal, U. S. 2012. Effect of grafting height and cultivars on the performance of soft wood grafting in mango, Asian Journal of Horticulture, 7(1): 171-174.

Mukherjee, S. K. 1998. Introduction: Botany and Importance. In Mango, Botany, 
Production and Uses. Edt. R.E. Litz., CAB International. pp. 1-20.

Palande, A. L., Karale, A. R., Shirnath, H. K. and Garad, B. V. 2004. Effect of season and genotypes on success and growth of bud grafts in tamarind. South Indian Journal of Horticulture, 52(1-6): 252255.

Panse, V. G. and Sukhatme, P. V. 1985. Statistical Methods for Agricultural Workers, ICAR, publication, New Delhi, pp. 381.

Patel, B. M. and Amin, R. S. 1981. Investigation in to the best period for softwood grafting of mangoes in situ. South Indian Horticulture, 29: 90-93.

Pereira, M. C. T., Viana, R. C., Correa, H. C. T., Nietsceh, S., Pinto, A. C. Q., Pereira M. E. C. and Alves, R. E. 2004. Studied on evaluation of grafting methods in mango trees. Proceeding of the Seventh International mango symposium, Recife city, Brazil, 22-27, September, 2002. Acta Hort. No. 645: 679-683.

Prasanth, J. M., Reddy, P. N., Patil, S. R. and Gouda, P. B. 2007. Effect of cultivars and time of softwood grafting on graft success and survival of mango. Agricultural Science Digest, 27(1): 1821.

Purbiati, T., Arief, A. and Suprapto. 1991. Effect of $\mathrm{GA}_{3}$ concentration and scion length on growth of mango minigrafts. J.I.P.M. (Institute-Pertanian-Malang). Indonesia, 1 (2): 48-51.

Rodrigues, J., Ryan, G. F. and Frolich, E. F. 1960. Some factors influencing grafting success with avocados. California avocado society, 44: 89-92.

Sharma, D. P. and Tiwari, B. L. 1995. Scientific Horticulture, 4: 1-5.

Singh, R. N., Rao, O. P. and Singh, G. 1984. Propagational studies in mango (Mangifera indica) cv. Langra. Progressive Horticulture, 16: 161-165.

Zimmerman, M. M. 1958. Translocation of organic substances in the phloem of trees. The physiology of forest trees, (Ed. K.V. Thimann). New York Ronald Press.

\section{How to cite this article:}

Ajay Kumar Karna, D.K. Varu, Manas Kumar Patel and Puja Archana Panda. 2018. Effect of Grafting Time on Success of Softwood Grafting in Mango (Mangifera indica L.). Int.J.Curr.Microbiol.App.Sci. 7(08): 3072-3077. doi: https://doi.org/10.20546/ijcmas.2018.708.327 